\title{
Short Communication \\ Possible protective effect of green tea intake on risk of adult leukaemia
}

\author{
M Zhang', X Zhao*,2, X Zhang ${ }^{2}$ and C D'Arcy J Holman' \\ 'The School of Population Health, The University of Western Australia, Perth, WA, Australia; ${ }^{2}$ Department of Hematology, Second Affiliated Hospital, \\ College of Medicine, Zhejiang University, Hangzhou 310009, PR China
}

In a case-control study of 107 adults with leukaemia and 110 orthopaedic controls in China, a reduced risk was found with longer duration, higher quantity, and frequency of green tea intake.

British Journal of Cancer (2008) 98, I68- I70. doi: I0.1038/sj.bjc.6604I40 www.bjcancer.com

Published online 18 December 2007

(c) 2008 Cancer Research UK

Keywords: adult leukaemia; case-control study; green tea; risk factor

Tea is one of the most frequently consumed beverages in the world (Graham, 1992). Different processing of tea leaves yields green, black, or Oolong tea. If tea leaves are immediately heated, then the enzymes that oxidise catechins are inactivated and the result is green tea; if crushed and allowed to undergo enzyme-mediated oxidation, the process results in black tea with its characteristic colour and taste. Oolong tea results from partially oxidised tea leaves (Graham, 1992).

There is some evidence of a protective effect of green tea consumption on certain cancers (Zhang et al, 2002; 2004; 2007; Cabrera et al, 2006), but no epidemiological data are available on the effect of green tea on adult leukaemia. We therefore conducted a case-control study of the question in southeast China.

\section{MATERIALS AND METHODS}

A hospital-based case-control study was conducted in Hangzhou, southeast China. Eligible cases were defined as Chinese, over 15 years old and resident in Zhejiang Province with leukaemia, histopathologically confirmed according to the haematological standards (Zhang, 1998). They were identified by daily searching of medical records in haematology wards at two teaching hospitals of Zhejiang University in 2005-2006; all medical records and laboratory reports were also reviewed to ensure complete ascertainment of cases. A total of 107 patients aged 16-81 years were recruited, most (83.2\%) were recent and were interviewed within 12 months of diagnosis. During the same period of data collection, 110 orthopaedic patients without leukaemia or other malignancy were randomly selected as controls to match the cases by age using a daily update of the list of cases. The project received approval from the hospital authorities and from the Human Research Ethics Committee of The University of Western Australia.

*Correspondence: Professor X Zhao; E-mail: zrxz@zju.edu.cn Received 28 June 2007; revised 31 October 2007; accepted 19 November 2007; published online 18 December 2007
Subjects were briefed regarding the aims of the study and confidentiality issues. After obtaining their consent, a face-to-face interview was conducted in the hospitals using a structured, validated questionnaire on (a) demography and lifestyle; (b) tea consumption; (c) hazard exposure and family history of malignancy. Most cases were recent patients interviewed within 3-6 months of diagnosis. Details of leukaemia subtype and stage were retrieved from hospital records.

Tea consumption was measured using a questionnaire adapted from our previous studies, its reproducibility evaluated in a testretest study where the intraclass correlation coefficient was 0.83 for tea (Zhang et al, 2005). Information was sought on preparation method, type of tea drank, duration of each type, frequency of cups $(350-400 \mathrm{ml})$, frequency of new batches of tea brewed, quantity of dried tealeaf consumed per year (in liang, equivalent to $50 \mathrm{~g}$ ), and date of cessation. Frequency of cups was categorised as never or seldom, once a month, 2-3 times a month, once a week, 2-3, 4-6 times a week, once a day, $2-3$, and $\geqslant 4$ times a day.

\section{Statistical analysis}

The data were coded and analysed using the SPSS package. As none of the participants reported drinking black or Oolong tea only and few (3.8\%) drank both green and black tea, all tea drinkers were classified as green tea drinkers. All comparisons used a $t$-test for continuous variables and $\chi^{2}$-test for categorical variables. Odds ratios (ORs) of adult leukaemia and associated 95\% confidence intervals (CIs) for green tea consumption as an explanatory variable were estimated using unconditional logistic regression. Multivariate models included potential confounders identified using univariate analysis and risk factors reported in other studies (Miligi et al, 1999; Ross et al, 2002; Kasim et al, 2005).

\section{RESULTS}

Of leukaemia subtypes, $72(67.3 \%)$ were acute myeloid leukaemia (AML), 22 (20.6\%) acute lymphocytic leukaemia (ALL), 10 (9.3\%) chronic myeloid leukaemia (CML), and 3 (2.8\%) chronic 
Table I Selected characteristics of cases and controls

\begin{tabular}{|c|c|c|c|}
\hline & $\begin{array}{c}\text { Cases } \\
(n=107)\end{array}$ & $\begin{array}{l}\text { Controls } \\
(n=110)\end{array}$ & P-value ${ }^{a}$ \\
\hline $\begin{array}{l}\text { Age at interview (years) } \\
15-<30 \\
30-<45 \\
45-<60 \\
\geqslant 60\end{array}$ & $\begin{array}{l}42.9 \pm 16.4 \\
25(23.3) \\
34(31.8) \\
28(26.2) \\
20(18.7)\end{array}$ & $\begin{array}{l}44.5 \pm 16.9 \\
24(21.8) \\
34(30.9) \\
27(24.5) \\
25(22.7)\end{array}$ & 0.46 \\
\hline $\begin{array}{l}\text { Gender } \\
\text { Male } \\
\text { Female }\end{array}$ & $\begin{array}{l}66(61.7) \\
41(38.3)\end{array}$ & $\begin{array}{l}70(63.6) \\
40(36.4)\end{array}$ & 0.77 \\
\hline $\begin{array}{l}\text { Locality of resident } \\
\text { Metropolitan } \\
\text { Suburb or rural area }\end{array}$ & $\begin{array}{l}29(27.1) \\
78(72.9)\end{array}$ & $\begin{array}{l}24(21.8) \\
86(78.2)\end{array}$ & 0.37 \\
\hline $\begin{array}{l}\text { Education } \\
\text { No formal education } \\
\text { Primary } \\
\text { Secondary } \\
\text { Tertiary }\end{array}$ & $\begin{array}{l}12(11.2) \\
24(22.4) \\
49(45.8) \\
22(20.6)\end{array}$ & $\begin{array}{c}6(5.4) \\
29(26.4) \\
66(60.0) \\
9(8.2)\end{array}$ & 0.02 \\
\hline $\begin{array}{l}\text { Tobacco smoking } \\
\text { Male smokers } \\
\text { Female smokers }\end{array}$ & $\begin{array}{c}29(43.9) \\
0(0)\end{array}$ & $\begin{array}{l}45(64.3) \\
3(7.5)\end{array}$ & $\begin{array}{l}0.02 \\
0.07\end{array}$ \\
\hline $\begin{array}{l}\text { Overall tea consumption } \\
\text { Green tea only } \\
\text { Black tea only } \\
\text { Oolong tea only } \\
\text { Green and black tea }\end{array}$ & $\begin{array}{l}45(42.1) \\
45(42.1) \\
0(0) \\
0(0) \\
0(0)\end{array}$ & $\begin{array}{l}61(55.4) \\
57(51.8) \\
0(0) \\
0(0) \\
4(3.6)\end{array}$ & $<0.05$ \\
\hline $\begin{array}{l}\text { Medication use of } \\
\text { chloromycetin }\end{array}$ & $6(5.6)$ & $0(0)$ & 0.01 \\
\hline $\begin{array}{l}\text { Occupational benzene } \\
\text { exposure }\end{array}$ & $16(15.0)$ & I (0.9) & $<0.001$ \\
\hline $\begin{array}{l}\text { Occupational } \\
\text { organophosphorus exposure }\end{array}$ & $5(4.7)$ & $0(0)$ & 0.02 \\
\hline
\end{tabular}

Values expressed as mean \pm s.d. or number (\%). ${ }^{\text {aT }}$ wo-sided $t$-test for continuous variables and $\chi^{2}$-test for categorical variables.

Table 2 Selected characteristics of green tea drinkers and nontea drinkers

\begin{tabular}{|c|c|c|c|}
\hline & $\begin{array}{c}\text { Green tea } \\
\text { drinkers }(n=106)\end{array}$ & $\begin{array}{c}\text { Nontea drinkers } \\
(n=I I I)\end{array}$ & P-value ${ }^{a}$ \\
\hline Age at interview (years) & $48.1 \pm 14.9$ & $39.5 \pm 17.2$ & $<0.001$ \\
\hline $\begin{array}{l}\text { Gender } \\
\text { Male } \\
\text { Female }\end{array}$ & $\begin{array}{l}76(71.7) \\
30(28.3)\end{array}$ & $\begin{array}{l}60(54.1) \\
51(45.9)\end{array}$ & $<0.01$ \\
\hline $\begin{array}{l}\text { Locality of resident } \\
\text { Metropolitan } \\
\text { Suburb or rural area }\end{array}$ & $\begin{array}{l}30(28.3) \\
76(71.7)\end{array}$ & $\begin{array}{l}23(20.7) \\
88(79.3)\end{array}$ & 0.19 \\
\hline $\begin{array}{l}\text { Education } \\
\text { No formal education } \\
\text { Primary } \\
\text { Secondary } \\
\text { Tertiary }\end{array}$ & $\begin{array}{c}9(8.5) \\
28(26.4) \\
51(48.1) \\
18(17.0)\end{array}$ & $\begin{aligned} 9 & (8.1) \\
25 & (22.5) \\
64 & (57.7) \\
13 & (11.7)\end{aligned}$ & 0.51 \\
\hline $\begin{array}{l}\text { Tobacco smoking } \\
\text { Male smokers } \\
\text { Female smokers }\end{array}$ & $\begin{aligned} 43 & (56.6) \\
1 & (3.3)\end{aligned}$ & $\begin{array}{l}31(51.7) \\
2(3.9)\end{array}$ & 0.40 \\
\hline
\end{tabular}

Values expressed as mean \pm s.d. or number (\%). ${ }^{a}$ Two-sided $t$-test for continuous variables and $\chi^{2}$-test for categorical variables. lymphocytic leukaemia (CLL). Selected characteristics are shown in Table 1. Cases were more educated, more exposed to chloromycetin, benzene, and organophosphorus, but fewer were smokers, especially among the men. Notably, only $42.1 \%$ of cases were tea drinkers compared with $55.4 \%$ of controls. Among the 106 tea drinkers, $96.2 \%$ drank green tea only. No other differences were found in the characteristics covered in Table 1.

Selected characteristics of green tea drinkers and nontea drinkers are presented in Table 2. Compared with nontea drinkers, green tea drinkers tended to be older and more often male (72 vs 54\%). There was no significant difference in residential area, education, or smoking.

Compared with nontea drinkers or infrequent tea drinkers, the adjusted ORs and associated 95\% CIs were 0.39 (0.17-0.91), 0.20 $(0.06-0.60), 0.40(0.19-0.82)$, and $0.42(0.20-0.86)$ in those who consumed green tea at $\geqslant 1001 \mathrm{~g}$ of dried tea leaves per annum, for $>20$ years, at $\geqslant 1$ cup a day, and at $\geqslant 1$ new batches a day, respectively (Table 3 ). A significant dose-response relationship between green tea consumption and adult leukaemia risk was observed across all measures; the reduced risk was seen for ALL and CML/CLL combined, but not for AML.

\section{DISCUSSION}

This case-control study found that higher intake of green tea was associated with a reduced risk of adult leukaemia and with

Table 3 Associations between green tea consumption and the risk of adult leukaemia

\begin{tabular}{|c|c|c|c|}
\hline & $\begin{array}{l}\text { No. of } \\
\text { cases }\end{array}$ & $\begin{array}{l}\text { No. of } \\
\text { controls }\end{array}$ & $\begin{array}{c}\text { Adjusted OR } \\
(95 \% \mathrm{Cl})^{\mathrm{a}}\end{array}$ \\
\hline \multicolumn{4}{|l|}{ Tea drinking } \\
\hline No & 62 & 49 & 1.0 (referent) \\
\hline Yes & 45 & 61 & $0.51(0.27-0.96)$ \\
\hline$P_{\text {trend }} \mathrm{b}$ & & & 0.04 \\
\hline \multicolumn{4}{|l|}{ Duration (years) } \\
\hline 0 & 62 & 49 & 1.0 (referent) \\
\hline$\leqslant 10$ & 20 & 21 & $0.68(0.30-1.53)$ \\
\hline$>10$ to $\leqslant 20$ & II & 17 & $0.66(0.26-1.72)$ \\
\hline$>20$ & 14 & 23 & $0.20(0.06-0.60)$ \\
\hline$P_{\text {trend }}{ }^{b}$ & & & $<0.01$ \\
\hline \multicolumn{4}{|l|}{ Number of cups } \\
\hline Nondrinkers or $\leqslant$ I time a week & 67 & 50 & I.0 (referent) \\
\hline 2-6 times a week & 10 & 13 & $0.40(0.14-1.14)$ \\
\hline$\geqslant 1$ time a day & 30 & 47 & $0.40(0.19-0.82)$ \\
\hline$P_{\text {trend }} \mathrm{b}$ & & & $<0.01$ \\
\hline \multicolumn{4}{|l|}{ Number of new batches } \\
\hline Nondrinkers or $\leqslant$ I time a week & 67 & 50 & 1.0 (referent) \\
\hline 2-6 times a week & 11 & 14 & $0.35(0.12-1.01)$ \\
\hline$\geqslant 1$ time a day & 29 & 46 & $0.42(0.20-0.86)$ \\
\hline$P_{\text {trend }} \mathrm{b}$ & & & 0.01 \\
\hline \multicolumn{4}{|l|}{ Dried tea leaves (gyear ${ }^{-1}$ ) } \\
\hline 0 & 62 & 49 & I.0 (referent) \\
\hline$\leqslant 500$ & 14 & 7 & $1.98(0.67-5.81)$ \\
\hline $501-1000$ & 12 & 16 & $0.20(0.07-0.62)$ \\
\hline$\geqslant 1001$ & 19 & 38 & $0.39(0.17-0.91)$ \\
\hline$P_{\text {trend }}{ }^{b}$ & & & $<0.01$ \\
\hline
\end{tabular}

$\mathrm{Cl}=$ confidence interval; $\mathrm{OR}=$ odds ratio. ${ }^{\text {aEstimates from separate unconditional }}$ logistic regression models included terms for age (years; continuous), gender (male, female), residence (metropolitan, suburb or rural), education (none, primary, secondary, tertiary), smoking (never/ever), medication use of chloromycetin (no/yes), occupational exposure to benzene (no/yes), and organophosphorus (no/yes). ${ }^{\text {b}}$ Two-sided test for trend across quantitative or ordinal quantitative variables. 
significant dose-response relationships, the first such evidence, although a US hospital-based case-control study recently reported a negative association between black tea and AML in women (Li et al, 2006). Our findings are consistent with experimental evidence that green tea polyphenols inhibited proteasome and induced apoptosis in leukaemic cells (Smith et al, 2002).

The few identified risk factors in adult leukaemia account for only a small proportion of cases and include ionising radiation, exposure to benzene, pesticides, immunosuppression, chemotherapy, and smoking (Miligi et al, 1999; Ross et al, 2002; Kasim et al, 2005). We found no significant association of smoking with leukaemia risk, the proportion of smokers being higher in the controls. No association was found between AML and green tea intake.

The case-control design may have introduced bias and the study size was relatively small, although recruitment was carefully conducted. The response rate was high, and the matched controls were randomly selected from the same hospitals. Most patients in China are self-referred, and the recruitment procedure ensured that cases and controls came from the same populations. Selection bias among controls from convenience or clinician contact was also minimised.

Details were obtained on tea consumption as well as on lifestyle factors and exposures using a validated instrument, designed for residents in southeast China. Our research interest in any type of tea consumption was revealed at the time of the interview to explain why the questions on tea were so detailed. We consider the likelihood of any information bias to have been low, and it is relevant that there had been no mention in the popular media of any link between tea and leukaemia.

We found a higher proportion of nontea drinkers than in previous studies and that tea drinking was associated with older age. Although tea consumption can be reported with reasonable accuracy, misclassification may still occur. However, when nondifferential, such errors are likely to bias results towards the null and could not account for the significant inverse associations. Exposure of cases to risk factors may change due to disease status, but most were newly diagnosed within 3-6 months.

In conclusion, this study suggests that a higher intake of green tea is associated with a reduced risk of adult leukemia, but the finding needs to be checked in larger studies.

\section{ACKNOWLEDGEMENTS}

We acknowledge with gratitude the participation of the subjects and the collaboration received from the participating hospitals and their staff, in particular, Professors Jie Jin and Yun Lian. M Zhang is supported by a postdoctoral fellowship from the National Health and Medical Research Council (Australia, ID 303292).

\section{REFERENCES}

Cabrera C, Artacho R, Gimenez R (2006) Beneficial effects of green tea - a review. J Am Col Nutr 25: 79-99

Graham HN (1992) Green tea composition, consumption and polyphenol chemistry. Prev Med 21: $334-350$

Kasim K, Levallois P, Abdous B, Auger P, Johnson KC, Canadian Cancer Registries Epidemiology Research Group (2005) Environmental tobacco smoke and risk of adult leukaemia. Epidemiology 16: 672-680

Li YL, Moysich KB, Baer MR, Weiss JR, Brasure J, Graham S, McCann SE (2006) Intakes of selected food groups and beverages and adult acute myeloid leukaemia. Leuk Res 30: 1507-1515

Miligi L, Seniori Costantini A, Crosignani P, Fontana A, Masala G, Nanni O, Ramazzotti V, Rodella S, Stagnaro E, Tumino R, Vigano C, Vindigni C, Vineis P (1999) Occupational, environmental, and life-style factors associated with the risk of hematolymphopoietic malignancies in women. Am J Ind Med 36: 60-69

Ross JA, Kasum CM, Davies SM, Jacobs DR, Folsom AR, Potter JD (2002) Diet and risk of leukemia in the Iowa women's health study. Cancer Epidemiol Biomarkers Prev 11: $777-781$

Smith DM, Wang Z, Kazi A, Li LH, Chan TH, Dou QP (2002) Synthetic analogs of green tea polyphenols as proteasome inhibitors. Mol Med 8: $382-392$

Zhang M, Binns CW, Lee AH (2002) Tea consumption and ovarian cancer risk: a case-control study in China. Cancer Epidemiol Biomarkers Prev 11: $713-718$

Zhang M, Binns CW, Lee AH (2005) A quantitative food frequency questionnaire for women in southeast China: development and reproducibility. Asia Pac J Public Health 17: 29-35

Zhang M, Holman CDJ, Huang J-P, Xie X (2007) Green tea and the prevention of breast cancer: a case-control study in southeast China. Carcinogenesis 28: $1074-1078$

Zhang M, Lee AH, Binns CW, Xie X (2004) Green tea consumption enhances survival of epithelial ovarian cancer. Int $J$ Cancer 112: $465-469$

Zhang ZN (ed) (1998) The Standards of Diagnosis and Treatment in Haematology, 2nd edn. Tianjin: Tianjin Science \& Technology Press 